\title{
POSSIBILITIES OF ZINC EXTRACTION FROM GALVANIC SLUDGES BY MEANS OF ELECTROLYSIS
}

\author{
1'Jaromír DRÁPALA, 'Daniel PETLÁK, 'Silvie BROŽOVÁ, ' Jitka MALCHARCZIKOVÁ, \\ 1'Sárka LANGOVÁ, ${ }^{1}$ Jiřina VONTOROVÁ, ${ }^{1}$ Hana RIGOULET, ${ }^{2}$ Václav NÉTEK, ${ }^{3}$ Jaroslav KUBÁČ, \\ ${ }^{3}$ Martina REKOVÁ, ${ }^{4}$ Jaroslav ŠVEC, ${ }^{4}$ Dominik JANÁČEK \\ ${ }^{1}$ VSB - Technical University of Ostrava, Ostrava, Czech Republic, EU, Jaromir.Drapala@vsb.cz \\ ${ }^{2}$ University of Entrepreneurship and Law, Ostrava, Czech Republic, EU, vaclav.netek@vspp.cz \\ ${ }^{3}$ GALVA s.r.o. Držovice, Czech Republic, EU, kubac@galva.cz \\ ${ }^{4}$ WANZL spol.s r.o., Hněvotín, Czech Republic, EU, Jaroslav.Svec@wanzl.cz
}

https://doi.org/10.37904/metal.2021.4244

\begin{abstract}
The aim of the work is a proposal of innovative technology of metal waste processing - sludges and filtration cakes from galvanizing plants. The paper deals with possibilities of zinc obtaining from waste of galvanic sludge, which arises during galvanic plating. A leaching process in an acid environment was optimized in the laboratory, resulting in separation of iron and organic components from sludge. The obtained leach was processed by means of the electrolysis in order to get pure zinc. Results of chemical analyses of individual products at the hydrometallurgical processes are presented in the article.
\end{abstract}

Keywords: Galvanic sludge, zinc, leaching, electrolysis, chemical analysis

\section{INTRODUCTION}

Galvanic zinc plating is an electrolytic process during which a zinc coating generated by electrochemical dissolution of a zinc anode deposits on electroconductive materials, mostly on iron parts (a cathode). For the galvanic process the alkaline or acidic coating can be chosen. Today zinc plating is typically carried out in a diluted hydrochloric acid with additions of other agents. According to shapes and sizes, zinc plated parts are either hung on hooks on a galvanic rack (larger parts) or they are placed into a drum (small parts). All automatic bath lines involve technological processes: degreasing, pickling, surface activation, galvanic deposition of zinc layers, passivation of zinc layers and application of sealing paints. Using automated conveyors, parts are gradually dipped into degreasing baths, pickling baths and a bath for the surface activation. After the surface of parts was cleaned, a new zinc layer has been deposited on it using electric current. Subsequently, in order to increase the corrosion resistance the zinc coating passivation is performed, in case of need a sealing paint is applied. All the zinc plating process is completed by air drying of parts and returning back to conveying units. The result of these processes is a high quality smooth surface with a shiny zinc layer. A standard thickness of the zinc coat ranges between $8-12 \mu \mathrm{m}$.

The technological process generates different kinds of wastes, such as pickling baths that have to be disposed after their saturation with dissolving metals, as they contain a high concentration of hydrochloric acid, zinc and iron. Rinsing water and spent pickle liquor are subsequently treated in four steps in neutralization stations. A resulting product of this treatment is a galvanic sludge that can contain up to $18 \mathrm{wt} \%$ of zinc and up to $8 \mathrm{wt} \%$ of iron. These concentrations are interesting enough for a proposal of an applicable recycling technology.

VŠB - Technical University Ostrava, Faculty of Materials Science and Technology has obtained a grant for a project No. SS1020312 „Innovative technology of the closed loop water circulation in the electro-galvanizing 
process and processing of metal waste - sludges and filtration cakes from the galvanizing plant". One of aims of this project is the proposal of technology of the waste sludge processing and obtaining of elemental metals as secondary raw material.

With rapidly developing galvanic plating, ever increasing attention has been focused on the galvanic sludge. Galvanic sludges feature a content of heavy metals, for example zinc, nickel, copper, cadmium and chromium. These sludges fall within hazardous waste by reason of potential releasing of metals to the living environment. Their disposal is carried out mostly by deposition [1,2]. In Germany sludge is disposed in incineration plants, if allowed by the sludge composition, or on hazardous waste dumps. One of often used possibilities of hazardous waste storage is its use for a protection and stabilization of abandoned parts of potash and salt mines $[3,4]$. At present every endeavor is made to avoid a negative impact related to sludge dumping and therefore various ways of processing are looked for.

In India the research is oriented on the solidification stabilization and the following use of sludge as a structural material [5]. A manufacture of clay bricks with an addition of galvanic sludge, where immobilization of heavy metals can be improved by adding waste glass, is described in [6]. The modern technologies development in Ukraine includes above all the use of the galvanic sludge as an inert filler in structural materials [7]. The sludge utilization as a sub-base material stabilized by cement and fly ash is solved in [8]. At the Northeast Normal University, China, the galvanic sludge re-use for a preparation of new adsorbents for waste water treatment has been brought into focus [9].

Galvanic waste processing through a vitrification method is described in [10,11]. A lot of researches have been oriented on re-gaining of different metals from the galvanic sludge, e.g. zinc and iron [2], nickel and chromium [12] or copper [13]. The main problem is a varied composition and a high content of heavy metals. On the other side, the sludge is a potential secondary source of heavy metals.

In accordance with the European Waste Catalogue sludges and filter cakes from neutralization stations belong among hazardous substances (cat. no. 110109 ). These are sludges of a solid and powdery consistency, yellow-green to brown color and a neutral reaction. Several hazardous properties were identified in them (H5, H13, H14) [14]. Galvanizing plant OEZ s.r.o. Letohrad contractually hands over wastes of 110109 group to World Resources Company, Wurzen, for recycling. Heavy metals (nickel, copper, zinc) can be recovered from galvanic sludges. These non-ferrous metal concentrates are delivered to metallurgical works as a free commercial product, where it is used as a raw material or a supplement for the production of primary metals or metal salts.

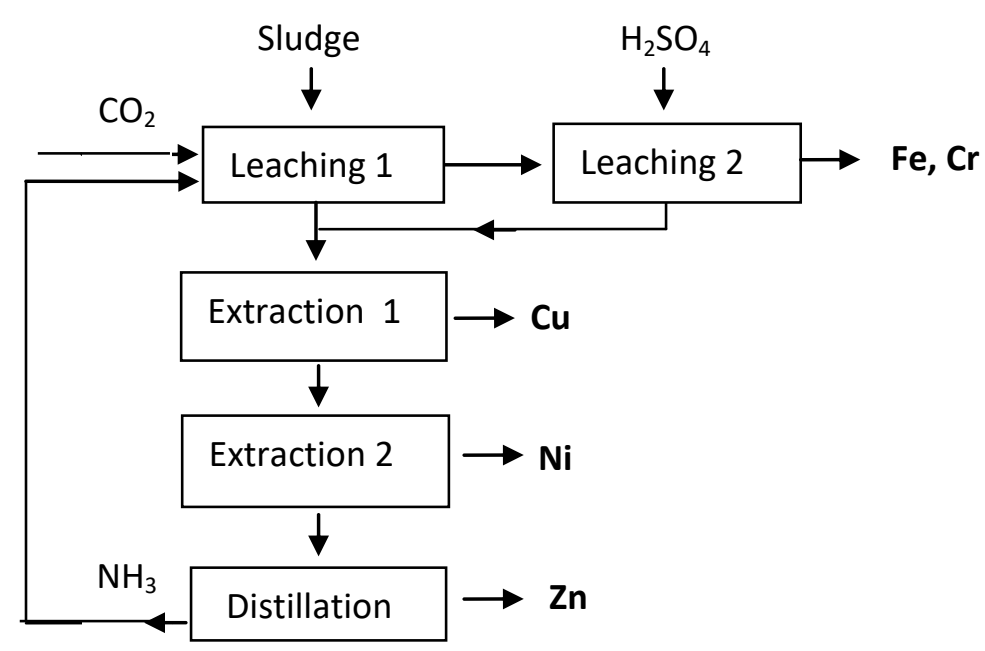

Figure 1 Block diagram of "MAR-Process" technology for galvanic sludge processing [16]
František Kepák has presented a technology based on metals recycling from the galvanic sludge - Figure 1 [15]. This is a so-called "MAR-Process", which allows a separation of non-ferrous metals from iron and chromium [16]. In the first step the ammonium carbonate is a leaching agent, $80 \%$ of non-ferrous metals is solved. An effectiveness of non-ferrous metals dissolution increases to $97-98 \%$ due to further leaching by the diluted sulfuric acid and approximately $98 \%$ of iron and chromium remains in the leach liquor that is dumped. $\mathrm{Cu}, \mathrm{Ni}$ and $\mathrm{Zn}$ are selectively separated from leaching solution by solvent extraction performed in particular steps. 
Electrolytic copper, nickel sulfate and nickel carbonate are final products.

The aim of this work is a proposal of an applicable procedure of leaching of galvanic sludge samples obtained from various galvanizing plants using a suitable leaching technology, separation of iron and zinc and subsequent obtaining of metal zinc through electrolysis.

\section{EXPERIMENTS}

Galvanic sludge samples were obtained from 6 different galvanizing plants in Olomouc Region and MoravianSilesian region. Results of X-ray analyses determined zinc content ranging between 5 to $35 \mathrm{wt} \%, 4-12 \mathrm{wt} \%$ of iron and up to $2 \mathrm{wt} \%$ of $\mathrm{Cr}$. In one case a high content of manganese about $8 \mathrm{wt} \%$ was found out, too.

Galvanic sludges from different galvanizing plants were processed in following ways: At first damp samples of waste sludge were treated by drying at approximately $100{ }^{\circ} \mathrm{C}$ and then homogenized by hand milling to an appropriate size of particles. The following solutions were used for the leaching process: $18 \%$ sulfuric acid, $12 \%$ nitric acid or $7 \%$ hydrochloric acid. Leaching was performed at temperatures of $40^{\circ} \mathrm{C}$ or $60{ }^{\circ} \mathrm{C}$, with an addition of hydrogen peroxide or ozone blowing. The aim of these experiments was to optimize the leaching process and to achieve the maximum dissolution of metals of interest from sludges. Partial results have been presented in [17]. It was found out that when sulphuric acid was used for leaching, a noticeable transition of metal elements to the leach occurs.

A content of zinc, iron, nickel and other metals in solutions was determined by a method of atomic absorption spectrometry (AAS) with the atomization process in a flame. Varian AA $280 Z$ spectrometer was used, including the integrated diluter system. The highest standards for a calibration curve were $2.5 \mathrm{mg} / \mathrm{l}$ for zinc and $5 \mathrm{mg} / \mathrm{l}$ for iron and nickel. The samples were stabilized by nitric acid.

In order to separate zinc from other metals, precipitation of the leach after acidic leaching through $\mathrm{NH}_{4} \mathrm{OH}$ was used. $10 \mathrm{~g}$ of the sludge sample was always dissolved in $100 \mathrm{ml}$ of the acid (see Table 1). The solution was diluted to $200 \mathrm{ml}$ and while slowly adding concentrated $\mathrm{NH}_{4} \mathrm{OH}, \mathrm{Fe}(\mathrm{OH})_{2}$ precipitate occurred. By adding $2 \mathrm{ml}$ of $\mathrm{H}_{2} \mathrm{O}_{2}$ hydrogen peroxide, ferruginous consistent precipitate $\mathrm{Fe}(\mathrm{OH})_{3}$ was formed. A filtration followed, then rinsing in $100 \mathrm{ml}$ of distilled water and in the end the precipitate was dried up. The results of $\mathrm{X}$-ray analyses (DELTA X Professional handheld $x$-ray spectrometer, ED-XRF method, SDD for radiation detection) for the particular samples after the above mentioned processing are shown in Table 1.

Table 1 Results of X-ray chemical analyses of precipitates (wt\% or wt. ppm) - an average of three measurements

\begin{tabular}{|l|l|l|l|l|l|l|l|l|l|l|l|l|l|}
\hline Leaching & $\mathbf{Z n}$ & $\mathbf{F e}$ & $\mathbf{M n}$ & $\mathbf{N i}$ & $\mathbf{C u}$ & $\mathbf{A s}$ & $\mathbf{Z r}$ & $\mathbf{M o}$ & $\mathbf{C d}$ & $\mathbf{S n}$ & $\mathbf{P b}$ & $\mathbf{C r}$ & $\mathbf{H g}$ \\
\hline $\mathbf{6 5 \%} \mathbf{H N O}_{3}$ & 4.4 & 14.5 & 1690 & 70 & 90 & 20 & 20 & 10 & -- & 50 & 100 & 5940 & --- \\
\hline $\mathbf{2 0} \% \mathbf{H}_{2} \mathbf{S O}_{4}{ }^{*}$ & 0.2 & 29.0 & 730 & 50 & 450 & 60 & 10 & 80 & -- & --- & --- & 550 & --- \\
\hline $\mathbf{2 0} \% \mathbf{H}_{2} \mathbf{S O}_{4}{ }^{* *}$ & 4.7 & 14.2 & 1010 & 20 & 70 & 20 & 20 & 10 & 40 & --- & 30 & 340 & --- \\
\hline $\mathbf{2 0} \% \mathbf{H C l}$ & 20.2 & 17.2 & 2320 & 210 & 410 & 80 & 100 & 10 & 110 & 100 & 80 & 7370 & 140 \\
\hline
\end{tabular}

* - the solution heated to $80{ }^{\circ} \mathrm{C}$ for a period of 30 min after $\mathrm{H}_{2} \mathrm{O}_{2}$ addition; ** - temperature $21^{\circ} \mathrm{C}$ after $\mathrm{H}_{2} \mathrm{O}_{2}$ addition.

After dissolving in $20 \% \mathrm{H}_{2} \mathrm{SO}_{4}{ }^{* *}$, the leach contained $4240 \mathrm{mg} / \mathrm{l}$ of $\mathrm{Zn}$ and $0.17 \mathrm{mg} / \mathrm{l}$ of $\mathrm{Fe}$ (AAS analysis).

After dissolving in $20 \% \mathrm{HCl}$, the leach contained $4160 \mathrm{mg} / \mathrm{l}$ of $\mathrm{Zn}$ and $0.13 \mathrm{mg} / \mathrm{l}$ of $\mathrm{Fe}$ (AAS analysis).

The results imply that the leach contained zinc, the Fe content was at minimum. So after leaching in sulphuric acid and subsequent precipitation using $\mathrm{NH}_{4} \mathrm{OH}$, a significant separation of zinc from iron occurred. 
The sludge with weight of $10 \mathrm{~g}$ from different suppliers was dissolved in $100 \mathrm{ml}$ of $20 \% \mathrm{H}_{2} \mathrm{SO}_{4}$ for a period of 4 hours. A filtration of undissolved solids followed, where the solid undissolved proportion was washed by distilled water and dried at $110{ }^{\circ} \mathrm{C}$ for a period of $24 \mathrm{~h}$. The filtrate was then precipitated using $25 \%$ solution of $\mathrm{NH}_{4} \mathrm{OH}$. The formed precipitate was oxidized using $20 \mathrm{ml}$ of $\mathrm{H}_{2} \mathrm{O}_{2}$ for a period of 3 hours; afterwards the precipitate was washed and dried at $110^{\circ} \mathrm{C}$. The samples of the particular filtrates were analyzed for zinc, iron, nickel and copper content - see Table 2.

Table 2 Chemical analyses of filtrates (AAS) - weights and contents of elements in solids after dissolving in $\mathrm{H}_{2} \mathrm{SO}_{4}$ and after the precipitation of iron using ammonia. A composition of the delivered sludge after having been dried-up is given as well (X-ray analysis)

\begin{tabular}{|c|c|c|c|c|c|c|c|c|c|c|}
\hline Supplier & $\begin{array}{c}\text { After leaching } \\
\text { in } 20 \% \mathrm{H}_{2} \mathrm{SO}_{4} \\
\text { (g) }\end{array}$ & $\begin{array}{c}\text { After } \\
\text { coagulation in } \\
\mathrm{NH}_{4} \mathrm{OH}(\mathrm{g})\end{array}$ & $\begin{array}{c}\mathrm{Zn} \\
(\mathrm{mg} / \mathrm{l})\end{array}$ & $\begin{array}{c}\mathrm{Fe} \\
(\mathrm{mg} / \mathrm{l} \\
)^{\prime}\end{array}$ & $\begin{array}{c}\mathrm{Ni} \\
(\mathrm{mg} / \mathrm{l} \\
)^{\prime}\end{array}$ & $\begin{array}{c}\mathrm{Cu} \\
(\mathrm{mg} / \mathrm{l} \\
)^{\prime}\end{array}$ & $\begin{array}{c}\mathrm{Zn}^{*} \\
(\mathrm{wt} \% \\
)\end{array}$ & $\begin{array}{c}\mathrm{Fe}^{*} \\
(\mathrm{wt} \% \\
)\end{array}$ & $\begin{array}{c}\mathrm{Ni}^{*} \\
(\mathrm{wt} \% \\
)\end{array}$ & $\begin{array}{c}\mathrm{Cu}^{*} \\
(\mathrm{wt} \% \\
)^{\prime}\end{array}$ \\
\hline D & 1.0 & 1.69 & 3394 & 0.223 & --- & 3.01 & 15.9 & 12.3 & --- & --- \\
\hline H & 5.74 & 3.62 & 8768 & 0.357 & 2.09 & 4.83 & 21.7 & 4.3 & 0.01 & 0.03 \\
\hline B & 1.24 & 2.18 & 11575 & 0.203 & 2.57 & 5.22 & 35.5 & 3.9 & 0.01 & 0.07 \\
\hline K & 2.47 & 3.62 & 4229 & 0.178 & 784 & 260 & 12.6 & 10.5 & 1.8 & 1.3 \\
\hline
\end{tabular}

Note: *The delivered galvanic sludge state (wt\%)

Zinc can be separated from aqueous solutions by electrolysis despite a significantly negative electrode potential $-0.763 \mathrm{~V}$. The electrolyte cleanliness, a condition of electrode surfaces and a current density are necessary for the proper electrolysis process. A presence of impurities in the electrolyte is a crucial issue for $\mathrm{Zn}$ separation by electrolysis. Impurities can be divided into three groups: Impurities more electronegative than $\mathrm{Zn}$ (e.g. Al, Mg, Mn) do not affect the $\mathrm{Zn}$ separation process directly, nevertheless their high concentration in the electrolyte increases the viscosity, thus restraining diffusion processes in the layer adjacent to electrodes. Impurities (e.g. $\mathrm{Pb}, \mathrm{Cd}$ and $\mathrm{Sn}$ ) the electrode potential of which ranges between $\mathrm{Zn}^{+}$and $\mathrm{H}^{+}$can be separated along with $\mathrm{Zn}$, contaminating the resulting product. However, some admixtures can be dissolved back (e.g. $\mathrm{Fe}, \mathrm{Co}, \mathrm{Ni}$ ), thus reducing the cathode current yield. More electropositive impurities than $\mathrm{Zn}$ (e.g. Cu, As, Sb, Ge etc.) have a harmful effect on the separated zinc. They form local cells on a cathode, resulting in dissolving of the separated $\mathrm{Zn}$, thus reducing the current yield [18].

Recommend parameters for the zinc electrolysis are as follows: $400-600 \mathrm{~A} \mathrm{~m}^{-2}$ current density, $2.5-3.5 \mathrm{~V}$ voltage on electrodes, $35-40^{\circ} \mathrm{C}$ electrolyte temperature. A cathode is usually made of aluminum plates of min. $99.5 \%$ purity, a material for an anode is usually a $\mathrm{Pb}$ plate with a small addition of $\mathrm{Ag}(0.5-0.85 \mathrm{wt} \%)$ for mechanical strength increasing. Cathode current yields range between $90-93 \%$ depending on the electrolyte cleanliness [18].

The first two experiments of electrolysis ( $\mathrm{H}$ supplier) were carried out as follows: $100 \mathrm{~g}$ of the sludge sample were dissolved in a $2000 \mathrm{ml}$ capacity beaker, in $1000 \mathrm{ml}$ of $20 \%$ (or $10 \%$ ) $\mathrm{H}_{2} \mathrm{SO}_{4}$ solution, for a period of 4 hours. After dissolving, the solution was filtered and rinsed by $300 \mathrm{ml}$ of distilled water on a fritted glass with a vacuum filtration. A proportion of solids was weighed after having been dried-up - $72.8 \mathrm{~g}$ (or $73.21 \mathrm{~g}$ ). The filtrate was evaporated to $1000 \mathrm{ml}$ volume. Further, after cooling-down the filtrate was precipitated using $\mathrm{NH}_{4} \mathrm{OH}$ solution $(250 \mathrm{ml})$, where $\mathrm{Fe}(\mathrm{OH})_{3}$ was precipitated in the form of a ferruginous precipitate. In order to accelerate oxidation, $5 \mathrm{ml}$ of concentrated hydroperoxide was added for a reaction period of 3 hours and subsequently the solution was gravitationally filtered. The rinsed precipitate was dried at $110{ }^{\circ} \mathrm{C}$ temperature for a period of $24 \mathrm{~h}$ and weighed $-53.21 \mathrm{~g}$ (or $55.12 \mathrm{~g}$ ). The filtrate was diluted by distilled water to $3000 \mathrm{ml}$ (or $2000 \mathrm{ml}$ ) and subjected to electrolytic precipitation for zinc. The bath temperature of $30{ }^{\circ} \mathrm{C}, 3 \mathrm{~V}$ voltage and 0.8 A current. 
The cathode was made of pure $\mathrm{Al}$, the anode was a $\mathrm{Pb}$ plate. Precipitated $\mathrm{Zn}$ was removed from the cathode, filtrated, rinsed, dried-up, weighed $-0.53 \mathrm{~g}$ (or $3.35 \mathrm{~g}$ ) and chemically analyzed afterwards. During the electrolysis the solution had $\mathrm{pH}=7$ (or $\mathrm{pH}=8$ ). The above mentioned results imply that the $2^{\text {nd }}$ experiment resulted in a higher zinc yield after the electrolysis - see Table 3.

Table 3 Results of chemical analyses of solid proportions ( $\mathrm{w} t \% \mathrm{or} \mathrm{mg} / \mathrm{kg}$ ) - an average of three measurements (supplier H)

\begin{tabular}{|l|c|c|c|c|c|c|c|c|c|c|c|}
\hline Sample & $\mathbf{Z n}^{*}$ & $\mathbf{Z n}$ & $\mathbf{F e}$ & $\mathbf{F e}$ & $\mathbf{M n}$ & $\mathbf{N i}$ & $\mathbf{C o}$ & $\mathbf{C u}$ & $\mathbf{P b}$ & $\mathbf{C r}$ & $\mathbf{H g}$ \\
\hline Delivered state & $21.7^{\star}$ & & $4.3^{*}$ & & $400^{*}$ & $100^{*}$ & & $300^{*}$ & & $1000^{*}$ & \\
\hline After leaching & $1.8^{*}$ & 3.4 & $2.34^{\star}$ & 2.76 & 392 & 77.3 & 3910 & 30.7 & 84.9 & 920 & 0.035 \\
\hline After coagulation of Fe & $6.57^{\star}$ & 6.88 & $13.5^{\star}$ & 16.9 & 2270 & 34.7 & 2250 & 35.0 & 31.4 & 5870 & 0.013 \\
\hline After electrolysis & $48.6^{*}$ & 59.3 & $0.19^{*}$ & $<0.01$ & 53.8 & 592 & 6230 & 959 & 614 & 93 & 0.08 \\
\hline
\end{tabular}

Methods of the analyses: ICP AES, US EPA apparatus, 6010 method. Mercury was determined by AMA 254 device. X-ray spectrometry - Delta X instrument (analyses marked ${ }^{*}$ )

Conditions of the $3^{\text {rd }}$ electrolysis experiment: Dissolution of $100 \mathrm{~g}$ of the sludge (B supplier) in $10 \%$ solution of $\mathrm{H}_{2} \mathrm{SO}_{4}$. A proportion of solids was weighed after having been dried-up $(60 \mathrm{~g})$. The filtrate was precipitated using $25 \%$ solution of $\mathrm{NH}_{4} \mathrm{OH}(250 \mathrm{ml})$ for $\mathrm{Fe}(\mathrm{OH})_{3}$. After having been dried-up, the precipitate had a weight of $67.4 \mathrm{~g}$. The electrolysis was performed under the following conditions: the bath temperature of $30^{\circ} \mathrm{C}, 3 \mathrm{~V}$ voltage, $0.8 \mathrm{~A}$ current, $\mathrm{pH}=8$. The precipitated $\mathrm{Zn}$ removed from the aluminum cathode had a weight of 7.93 $\mathrm{g}$, which was more than in foregoing experiments. A photographic image of the product after the electrolysis is shown in Figure 2. Chemical analyses have not yet been carried out.
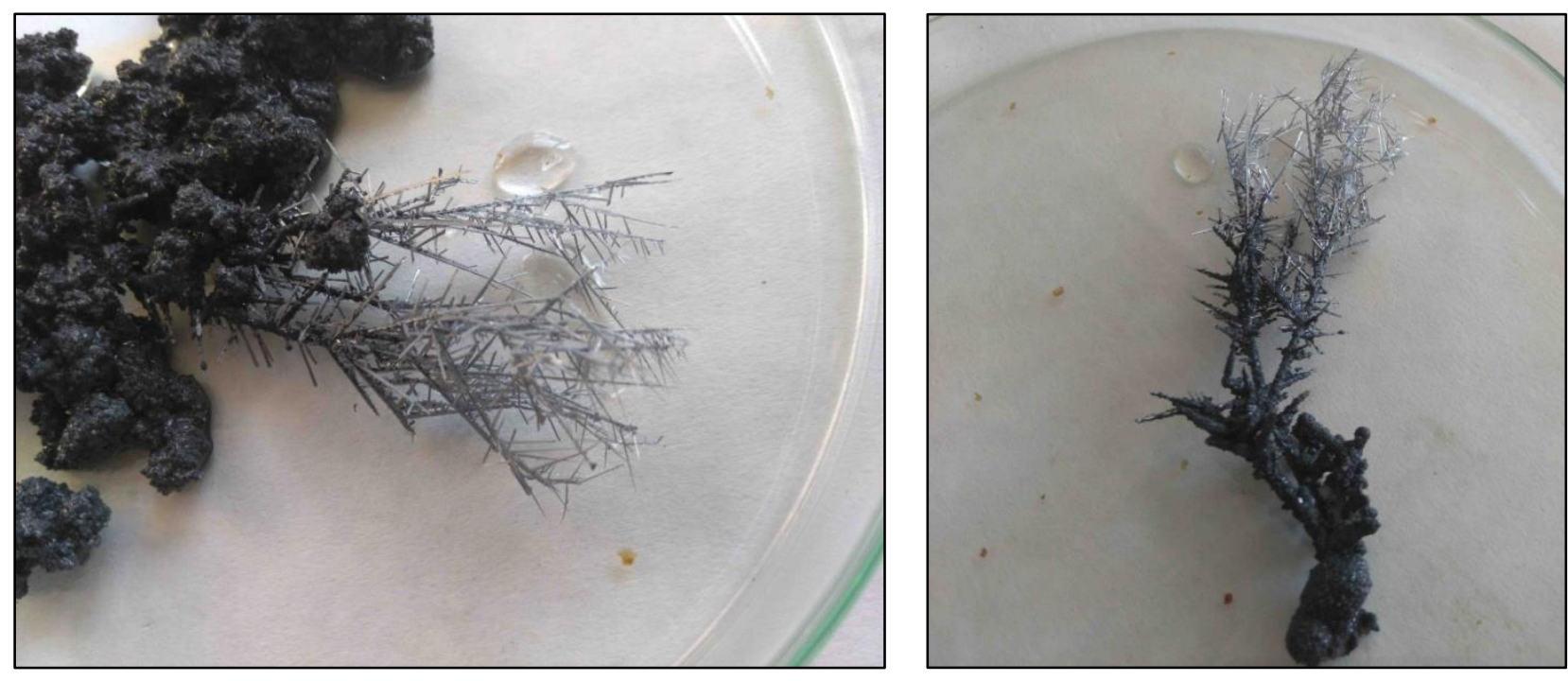

Figure 2 Photo of the separated zinc on the cathode after the electrolysis (the $3^{\text {rd }}$ experiment)

\section{DISCUSSION}

Within the experiments mentioned above, the aim was to find optimal conditions for leaching of the galvanic sludge with a high $\mathrm{Zn}$ and $\mathrm{Fe}$ content obtained from six different galvanizing plants. $\mathrm{HNO}_{3}, \mathrm{H}_{2} \mathrm{SO}_{4}$ and $\mathrm{HCl}$ acids were applied at different temperatures and periods of leaching, possibly with an addition of $\mathrm{H}_{2} \mathrm{O}_{2}$ or ozone [17]. $\mathrm{H}_{2} \mathrm{SO}_{4}$ acid worked best. For separation of $\mathrm{Zn}$ and $\mathrm{Fe}$ the ammonia was used, when iron 
precipitation in the form of $\mathrm{Fe}(\mathrm{OH})_{2}$ occurred, or $\mathrm{Fe}(\mathrm{OH})_{3}$ after adding $\mathrm{H}_{2} \mathrm{O}_{2}$. The results confirmed unambiguously the $\mathrm{Zn}$ separation from $\mathrm{Fe}$ in the filtrate - see Table 2. During the subsequent electrolysis different conditions were tested. The electrolyte temperature of $30^{\circ} \mathrm{C}, 3 \mathrm{~V}$ voltage, $0.8 \mathrm{~A}$ current and $\mathrm{pH}=8$ seem to be optimal. The obtained product on the cathode contained $58 \mathrm{wt} \%$ of $\mathrm{Zn}$, the Fe content was neglectable - see Table 3. In this phase there were laboratory-scale experiments.

\section{CONCLUSION}

In this work, experiments of galvanic sludge leaching, iron precipitation using $\mathrm{NH}_{4} \mathrm{OH}$ and following electrolysis with the aim to obtain metals of interest were performed. The conditions and results of these experiments are described in the text and shown in the relevant tables. In the follow-up phase we will focus on optimization of particular processes parameters, so that we can obtain zinc as pure as possible, suitable for further application in galvanizing plants. A further step will be a transition from the laboratory scale to a pilot plant process.

\section{ACKNOWLEDGEMENTS}

This work was solved in the frame of the project of Technological Agency of Czech Republic No. SS1020312 „Innovative technology of the closed loop water circulation in the electro-galvanizing process and processing of metal waste - sludges and filtration cakes from the galvanizing plant".

\section{REFERENCES}

[1] ALVES, L.A., AMATO-LOURENÇO, L.F., MIRAGLIA, S.G.E.K., SEO, E.S.M. Environmental valuation of the galvanic solid waste generated in a chroming process. [online]. Available from:

https://www.ipen.br/biblioteca/2012/eventos/18490.pdf.

[2] MICZKOVÁ, J. Processing of metal-bearing wastes - sludge and filter cake from the operation of the galvanizing plant. 2020, 147 p. Thesis. Vysoká škola báňská - Technical University of Ostrava.

[3] Was gehört zur Abfallart Galvanikschlämme, was nicht? Remondis-entsorgung. [online]. Available from: https://www.remondis-entsorgung.de/abfallarten/galvanikschlage.

[4] Treatment with wastes. K+S [online]. Available from: http://www.ks-cz.com/cs/products/waste-management.html.

[5] VARINDER, K., SIBY, J. Use of electroplating industry sludge as a construction material. [online]. 2017. Available from: https://doi.org/10.15406/mojce.2017.02.00024.

[6] MAO, L., GUO, H., ZHANG, W. Addition of waste glass for improving the immobilization of heavy metals during the use of electroplating sludge in the production of clay bricks. [online]. Available from:

https://doi.org/10.1016/j.conbuildmat. 2017.12.177.

[7] TKACH, D. Study the possibility of heavy metals extraction from electroplanting sludges [online]. Available from: http://masters.donntu.org/2014/feht/tkach/diss/indexe.htm\#P1.

[8] ZHANG, YU, SHI, P., CHEN, L., QIANG TANG. Utilization of electroplating sludge as subgrade backfill materials: Mechanical and environmental risk evaluation. [online]. Available from: https://doi.org/10.1155/2018/4891418.

[9] LIU, Y., KHAN, A.,WANG, Z., CHEN, Y., ZHU, S., SUN, T., LIANG, D., YU, H. Upcycling of electroplating sludge to prepare erdite-bearing nanorods for the adsorption of heavy metals from electroplating wastewater effluent. [online]. 2020. Available from: https://doi.org/10.3390/w12041027.

[10] CUBAS, A., VIEIRA, L., MACHADO, M.M., GROSS,F., MAGNAGO, R.F., MOECKE, E.H.S., DE SOUZA, I.G. Inertization of heavy metals present in galvanic sludge by DC thermal plasma. [online]. 2018. Available from: https://doi.org/10.1021/es404296x.

[11] OZDEMIR, O.D., FIGEN, A.K., PISKIN, S. Utilization of galvanic sludge as raw material for production of glass. [online]. 2011. Available from: http://www.ipcbee.com/vol10/9-V00019.pdf

[12] GAROLE, D.J., GAROLE, V.J., DALAL, D. Recovery of metal value from electroplating sludge. [online]. 2012. Available from: https://www.researchgate.net/publication/259929267. 
[13] DANG, T.D., TUNG, M.T., HUYEN, N.T.T., GREEN, T.A., ROY, S. Electrochemical copper recovery from galvanic sludge. [online]. 2016. Available from: https://doi.org/10.1016/j.hydromet.2016.06.028

[14] KOŠÁRKOVÁ, M. Galvanizing plants try to recycle the maximum of their wastes. [online]. Available from: https://www.odpady-online.cz/galvanovny-se-snazi-recyklovat-maximum-svych-odpadu/.

[15] KEPÁK, F. Industrial wastes. Monograph. Part 1. Jan Evangelista Purkyně University in Ústí nad Labem, Faculty of Environment. Ústí nad Labem, 2005, p. 201.

[16] JANDOVÁ J., LENCOVÁ, S. Recycling of zinc from waste galvanic sludges. In: Proceedings "Wastes, Prague 98". SOP ČR Prague, 1998, pp. 44-47.

[17] BROŽOVÁ, S., DRÁPALA, J., MICZKOVÁ, J., HAVRÁNEK, J. Possibilities of obtaining zinc and iron after leaching of galvanic sludges. In: METAL 2020 $29^{\text {th }}$ International Conference on Metallurgy and Materials. Ostrava: TANGER, 2020, pp. 892-896.

[18] JANDOVÁ J., WU Nguyen Hong, DVOŘÁK, P. Methods of production of non-ferrous metals and treatment of wastes. University of Chemistry and Technology Prague, 2018, $312 \mathrm{p}$. 